\title{
Acute Kidney Injury Secondary to Vitamin D Toxicity: Report of Two Cases
}

Khurshid A. Banday, M.D., Mohammad Ashraf Bhat, M.D., Nazir A. Palla, M.D., Tufail Ahmad, M.D., Abdul Rashid Reshi, M.D., Mohammad Saleem Najar, M.D.

Department of Nephrology, Sher-i-Kashmir of Institute of Medical Sciences Srinagar, Kashmir (J\&K)

\section{A B S T R A C T}

We present two patients with hypercalcemia and acute kidney injury from intentional overdose of injectable vitamin D supplement. The patients presented to the nephrology department with varied clinical manifestations. Both had received a cumulative dose of vitamin $\mathrm{D}$ in millions of units. Both made a complete clinical recovery after hydration and low dose steroids. These cases highlight the need for caution when using unregulated injectable form of vitamin D. JMS 2011 ; 1 4(2):63-65

Keywords: Vitamin D, acute kidney injury, hypercalcemia

Vitamin D toxicity is a known cause of hypercalcemia and acute kidney injury. ${ }^{1,2}$ It can be due to accidental ingestion, faulty food fortification, self medication and malpractice related excessive administration. ${ }^{3-7}$ Its incidence has been on the up in Kashmir valley and more cases are reporting to hospitals with complications. ${ }^{8}$ We report here 2 cases of malpracticerelated vitamin D intoxication who presented with hypercalcemia, acute kidney injury and mental obtundation.

\section{Case 1}

A 70 year old male, hypertensive for 10 years (on amlodipine), hypothyroid (on $75 \mu \mathrm{g}$ thyroxine) was admitted with altered sensorium, polyuria and constipation. There was no history of vomiting, fever, weakness of any part of body. There was history of multiple injections of Vitamin $\mathrm{D}_{3}(2$ injections of Arachitol 6 lac units / week for 2 months), for

\footnotetext{
Correspondence and Reprint requests to:

Dr Khurshid A Banday

Additional Professor,

Department of Nephrology,

Sher-i-Kashmir Institute of Medical Sciences, Srinagar, J\&K. kabanday@gmail.com
}

arthralgias and generalized debility, a cumulative dose in millions of units. Examination revealed patient in grade 2 encephalopathy, grossly dehydrated, pulse of 52 beats/min, regular, B P of 160/100mmHg with a normal chest, abdominal examination. Cardiovascular examination revealed bradycardia and CNS examination showed no neck rigidity, grade 2 encephalopathy with no focal neurodeficit. Routine chemistry revealed- Hb $10.5 \mathrm{~g} / \mathrm{dL}$, TLC $8.9 \times 10^{9} / \mathrm{L}$, DLC: N $64 \%$, L $24 \%$, platelet $150 \times 10^{9} / \mathrm{L}$, ESR 12 , urea $117 \mathrm{mg} / \mathrm{dL}$, creatinine $2.5 \mathrm{mg} / \mathrm{dL}(0-1.5 \mathrm{mg} / \mathrm{dL})$, glucose $99 \mathrm{mg} / \mathrm{dL}$, serum calcium $14.2 \mathrm{mg} / \mathrm{dL}(9.5-11.5 \mathrm{mg} / \mathrm{dL})$, serum phosphorus $3.6 \mathrm{mg} / \mathrm{dL}$ (3.5-5.5 mg/dL), uric acid $6.6 \mathrm{mg} / \mathrm{dL}, \mathrm{LDH} 330 \mathrm{U} / \mathrm{L}$, total protein $6.6 \mathrm{~g} / \mathrm{dL}$, albumin $4.0 \mathrm{~g} / \mathrm{dL}$, bilirubin $0.75 \mathrm{mg} / \mathrm{dL}$, SGOT 35 U/L, SGPT 40 U/L, ALP 210 U/L. Urine examination was normal, $24 \mathrm{~h}$ urinary proteins $0.15 \mathrm{~g} /$ day, the $24 \mathrm{~h}$ urinary calcium $350 \mathrm{mg}$. Serum PSA was normal and his serum electrophoresis was normal, chest X-ray revealed cardiomegaly with prominent aortic knuckle, electrocardiography revealed sinus bradycardia with a QT interval of $0.40 \mathrm{sec}$. An abdominal and a neck ultrasound were normal. A non contrast CT scan of head was normal. Serum PTH was $13.5 \mathrm{pg} / \mathrm{ml}(15-68 \mathrm{pg} / \mathrm{ml})$, Vitamin D $(25 \mathrm{OH})$ was $375 \mathrm{nmol} / \mathrm{ml}$ (intoxication level $>250$ ). The patient was managed for hypertension, hypothyroidism (under treated) and Vitamin D induced 
hypercalcemia with acute kidney injury. Patient was given antihypertensive, intravenous fluids, low dose steroids, proton pump inhibitors and his thyroxine dose was increased. The level of serum calcium on the 5 th day of treatment was 10.2 $\mathrm{mg} / \mathrm{dL}$, that of phosphorus was $3.94 \mathrm{mg} / \mathrm{dL}$, and the creatinine level stabilized at $1.5 \mathrm{mg} / \mathrm{dL}$. Hypercalcemia improved, patient became conscious, dehydration got corrected and creatinine showed a downward trend. Patient was discharged in a stable condition and is on follow up with normal calcium and renal functions.

\section{Case 2}

A 38 year old female, normotensive, presented with generalized weakness of six months duration and recent onset intermittent vomiting. She was referred with azotemia \& proteinuria. She denied any history of fever, pain abdomen, loose stools, arthralgias and rash. She gave history of taking multiple injections of Protobol (anabolic steroid) \& Vitamin D (6 lac units) once in a fortnight for past 2 years. On examination she had a lean built, was conscious, oriented, dehydrated, no pallor, no lymphadenopathy. Her chest, CVS, abdominal and neurological examination was normal. Laboratory investigations showed a Hb $12.5 \mathrm{~g} / \mathrm{dL}$, TLC $8.0 \times 10^{9} / \mathrm{L}$, DLC: N $75 \%$, L 20\%, platelet $120 \times 10^{9} / \mathrm{L}$, ESR 08/1st hour, urea $88 \mathrm{mg} / \mathrm{dL}$, creatinine $3.5 \mathrm{mg} / \mathrm{dL}(0-1.5 \mathrm{mg} / \mathrm{dL})$, glucose $99 \mathrm{mg} / \mathrm{dL}$, serum calcium $13.2 \mathrm{mg} / \mathrm{dL}(9.5-11.5 \mathrm{mg} / \mathrm{dL})$, serum phosphorus 4.5 $\mathrm{mg} / \mathrm{dL}$ (3.5-5.5 mg/dL), uric acid $6.6 \mathrm{mg} / \mathrm{dL}, \mathrm{LDH} 320 \mathrm{U} / \mathrm{L}$, total protein $6.5 \mathrm{~g} / \mathrm{dL}$, albumin $3.8 \mathrm{~g} / \mathrm{dL}$, bilirubin $0.8 \mathrm{mg} / \mathrm{dL}$, SGOT 28 U/L, SGPT 30 U/L, ALP 220 U/L. Urine showed $2+$ proteins, no RBC's, no WBC's, and her 24 hour urinary proteins was 1.2 grams, the $24 \mathrm{~h}$ urinary calcium $320 \mathrm{mg}$. Her serum electrophoresis was normal as was her chest X-ray and electrocardiography. An abdominal and a neck ultrasound were normal. Serum PTH was 6 pg/ml (15-68pg/ml), Vitamin D (25 $\mathrm{OH}) 375 \mathrm{nmol} / \mathrm{ml}$. The patient was managed with antihypertensive, intravenous fluids, steroids, and proton pump inhibitors. She was discharged with a creatinine of $2.4 \mathrm{mg} / \mathrm{dl}$ and her calcium decreased to $10.2 \mathrm{mg} / \mathrm{dl}$. In three months of her follow up she has shown a decline in her serum creatinine to $1.8 \mathrm{mg} / \mathrm{dl}$ and her serum calcium is within normal limits.

\section{Discussion}

Vitamin D deficiency is not uncommon in "sunny" India. ${ }^{9-11}$ The daily requirement of vitamin D is about 200-600 IU and it is mainly produced in the skin after total body exposure to UV light. Sunlight exposure from November through February in north India is insufficient to produce significant vitamin D in the skin. ${ }^{10,11}$ The season, the geographic latitude, the time of day, cloud cover, smog, and sunscreen affect UV exposure and vitamin D synthesis. ${ }^{12-14}$ Most of northern India, including Kashmir has been established as a vitamin $\mathrm{D}$ deficient zone. ${ }^{15-20}$ In the Kashmir valley, the prevalence of vitamin D deficiency is quite high, $69.6 \%$ in individuals exposed to the outdoors to $100 \%$ in those confined indoors, reflecting the lower mean weekly exposure to sunlight. $^{21}$ The prevalence of vitamin D deficiency among elderly people can be estimated to be at least $50 \%$, whereas it has been reported in $80 \%$ of "veiled" pregnant women.

The clinical spectrum ranges from subclinical to frank deficiency with serum 25-hydroxyvitamin D (25OHD) levels less than $20 \mathrm{nmol} / \mathrm{L}^{22-25}$ Vitamin D repletion in individuals presenting with vitamin $\mathrm{D}$ deficiency has been shown to have a positive effect on bone biology, resulting in mineralisation of osteoid, increases in bone mineral density measurements and reduced fracture rates. ${ }^{26}$ This has led to overzealous use of vitamin D particularly in Kashmir valley where it is being prescribed or even given without prescription for non descript symptoms. ${ }^{8}$ Vitamin D repletion can improve bone mineral density and reduce fracture risk. In the absence of adequate sunlight exposure, supplementation becomes important. The target for vitamin $\mathrm{D}$ supplementation is suggested to be a serum level of $50 \mathrm{nmol} / \mathrm{L}$, which is protective against secondary hyperparathyroidism and decreased bone density.

Vitamin D toxicity has been reported either due to over fortified food supplements taken accidentally for prolonged period, after the topical application of vitamin D ointment or iatrogenic in some unusual cases especially after injectable form. ${ }^{2-5}$ The excessive and prolonged use of injectable form can lead to vitamin D intoxication. Excretion of vitamin D is negligible and hence excessive administration can lead to toxicity. The clinical manifestations of this intoxication are kidney disorders (65\%), renal insufficiency (51\%), gastrointestinal tract disorders (23\%), and arterial hypertension (52\%). Symptoms may include-weakness, polyuria, intense thirst, weight loss, nausea, vomiting, difficulty in speaking and confusion. Patient may lapse into coma, while cardiac arrhythmias and renal failure can occur. These effects are due to hypercalcemia induced by increased intestinal absorption and mobilization of calcium from bone. ${ }^{1,4,5}$

These two cases of Vitamin D intoxication are a continuum of many such cases being seen in the Nephrology department on intermittent basis over last two years. ${ }^{1,8}$ Both our patients had received massive doses of slow-release preparation of vitamin $\mathrm{D}$ for a prolonged period of time leading to a cumulative dose of millions of units. This emphasizes the need to regularly assess the levels of vitamin D in patients suspected of its deficiency and who are put on vitamin $\mathrm{D}$ replacement therapy. Also a general awareness about the potential toxic effect of excessive use of injectable vitamin $\mathrm{D}$ needs to be done at the district and village level.

\section{References}

1. Naik MA, Banday KA, Najar MS, Reshi AR, Bhat MA. Vitamin D intoxication presenting as acute renal failure. Indian J Nephrol 2008;18:125-6.

2. Barrueto F Jr, Wang-Flores HH, Howland MA, Hoffman RS, Nelson LS. Acute Vitamin D Intoxication 
in a Child. Pediatrics 2005;116:e453-6.

3. Koutkia P, Chen TC, Holick MF. Vitamin D intoxication associated with an over-the-counter supplement. N Engl JMed 2001;345:66-67.

4. Dietary Supplement-Induced Vitamin D Intoxication. NEnglJ Med 2007;357:308-309.

5. Vasudevan AR, Raju JM, Ganesh A, John L. Symptomatic hypercalcaemia due to vitamin $\mathrm{D}$ intoxication.J Assoc Physicians India 1991;39:972.

6. Chambellan-Tison C, Horen B, Plat-Wilson G, Moulin P, Claudet I. Severe Hypercalcemia due to vitamin D intoxication. Arch Pediatr 2007;14:1328-32.

7. Chiricone D, De Santo NG, Cirillo M. Unusual cases of chronic intoxication by vitamin D. J Nephrol 2003;16: 917-21.

8. Koul P, S Hilal, F Ahmed, R Jan, S Shah, U Khan. Vitamin D Toxicity in Adults:A case series from an area of endemic Hypovitaminosis D. Oman Med J 2011;26(3): 201-4.

9. Joshi SR. Vitamin D paradox in plenty sunshine in rural india-an emerging threat. J Assoc Physicians India 2008; 56:749-52.

10. Goswami R, Kochupillai N, Gupta N, Goswami D, Singh N, Dudha A. Presence of 25(OH)D deficiency in rural north Indian village despite abundant sunshine. $J$ Assoc Physicians India 2008;56:755-57.

11. Sahu M, Bhatia V, Aggarwal A, Rawat V, Saxena P, Pandey A, Das V. Vitamin D deficiency in rural girls and pregnant women despite abundant sunshine in northern India. Clin Endocrinol (Oxf) 2008;612-5.

12. Mishal AA. Effects of different dress styles on vitamin D levels in healthy Jordanian women. Osteoporosis Int 2001; 12:931-5.

13. Need AG, Morris HA, Horowitz M, Nordin BEC. Effects of skin thickness, age, body fat and sunlight on serum 25-hydroxyvitamin D. Am J Clin Nutr 1993;58: 882-85.

14. Sherman SS, Hollis BW, Tobin JD. Vitamin D status and related parameters in a healthy population: the effects of age, sex and season. J Clin Endocrinol Metab 1990;71: 405-13.

15. Goswami R, Gupta N, Goswami D, et al. Prevalence and significance of low 25- hydroxyvitamin D concentrations in healthy subjects in Delhi. Am J Clin Nutr 2000;72:472-5

16. Sachan A, Gupta R, Das V, Agarwal A, Awasthi PK, Bhatia V. High prevalence of vitamin D deficiency among pregnant women and their newborns in northern India. Am JClin Nutr 2005;81:1060-4.

17. Puri S, Marwaha RK, Agarwal N, Tandon N, Agarwal R, Grewal K, Reddy DH, Singh S. Vitamin D status of apparently healthy schoolgirls from two different socioeconomic strata in Delhi: relation to nutrition and lifestyle. BrJ Nutr 2008;99:876-82.

18. Marwaha RK, Tandon N, Reddy DR, Aggarwal R, Singh R, Sawhney RC, Saluja B, Ganie MA, Singh S. Vitamin D and bone mineral density status of healthy schoolchildren in northern India. Am J Clin Nutr 2005;82:477-82.

19. Rajeswari J, Balasubramanian K, Bhatia V, Sharma VP, Agarwal AK. Aetiology and clinical profile of osteomalacia in adolescent girls in northern India. Natl Med J India 2003;16:139-42.

20. Vupputuri MR, Goswami R, Gupta N, Ray D, Tandon N, Kumar N. Prevalence and functional significance of 25-hydroxyvitamin D deficiency and vitamin D receptor gene polymorphisms in Asian Indians. Am J Clin Nutr 2006;83:1411-9.

21. Zargar AH, Ahmad S, Masoodi SR, Wani AI, Bashir MI, Laway BA, Shah ZA. Vitamin D status in apparently healthy adults in Kashmir Valley of Indian subcontinent. Postgrad Med J 2007;83:713-6.

22. Weaver CM, Fleet JC. Vitamin D requirements: current and future. AmJ Clin Nutr 2004;80(suppl):1735S-9S.

23. Lips P, Chapuy MC, Dawson-Hughes B, Pols HAP, Holick MF. International comparison of vitamin D measurements. Osteoporos Int 1999;9:394-97.

24. Lips P. Vitamin D deficiency and secondary hyperparathyroidism in the elderly: consequences for bone loss and fractures and therapeutic implications. Endocr Rev 2001; 22:477-501.

25. Parfitt AM, Gallagher JC, Heaney RP, Johnston CC, Neer P, Whedon G. Vitamin D and bone disease in the elderly. Am JClin Nutr 1982;32:1014-31.

26. Szulc P, Meunier PJ. Synergistic effect of vitamin D and calcium in preventing proximal femoral fractures in older patients.Joint Bone Spine 2003;70:157-60. 